\title{
Miranda
}

Revue pluridisciplinaire du monde anglophone /

Multidisciplinary peer-reviewed journal on the English-

speaking world

$12 \mid 2016$

Mapping gender. Old images ; new figures

\section{"This rushing cosmos filled her with a bleak dismay": The Textual/Sexual Dynamics of Speed in The Revenge for Love by Wyndham Lewis}

\section{Annelie Fitzgerald}

\section{OpenEdition}

\section{Journals}

Electronic version

URL: http://journals.openedition.org/miranda/8626

DOI: $10.4000 /$ miranda.8626

ISSN: 2108-6559

\section{Publisher}

Université Toulouse - Jean Jaurès

\section{Electronic reference}

Annelie Fitzgerald, "'This rushing cosmos filled her with a bleak dismay": The Textual/Sexual Dynamics of Speed in The Revenge for Love by Wyndham Lewis", Miranda [Online], 12 | 2016, Online since 02 March 2016, connection on 16 February 2021. URL: http://journals.openedition.org/miranda/ 8626 ; DOI: https://doi.org/10.4000/miranda.8626

This text was automatically generated on 16 February 2021.

\section{c)}

Miranda is licensed under a Creative Commons Attribution-NonCommercial-NoDerivatives 4.0

International License. 


\title{
"This rushing cosmos filled her with a bleak dismay": The Textual/Sexual Dynamics of Speed in The Revenge for Love by Wyndham Lewis
}

\author{
Annelie Fitzgerald
}

\section{Introduction}

1 The climax of Wyndham Lewis's novel, The Revenge for Love (1937), depicts the female protagonist, Margot Stamp, hurtling towards the Pyrenees in a bootlegger's automobile driven by her husband, Victor. Written between 1934 and 1935 when he was seriously ill, Lewis's novel is set amid the political upheaval that preceded the Spanish Civil War; as several critics have observed, it masterfully combines features of popular fiction, such as suspense and the pursuit scene typical of the thriller and the adventure novel, with political and social satire. ${ }^{1}$ Shortly before its publication Lewis wrote that he considered this novel "probably the best complete work of fiction I have written" (Rose 242), a verdict which has since been upheld by many of his readers and critics. In a letter to the literary critic Julian Symons, editor in 1937 of a special Wyndham Lewis Number of Twentieth Century Verse, Lewis underlined the care the novel's composition had demanded of him: "Very naturally, a page of a novel, such as The Revenge for Love, takes me as long to write as twenty pages of a Blasting and Bombardiering [Lewis's 1937 autobiography]" (Rose 247). The focus of this study is on the twenty or so extraordinary pages of narrative which form the antepenultimate and penultimate chapters of the novel, part of the section titled "Honey-Angel", where the suspense reaches its climax. My aim is to analyse some of the (inter-)textual elements at work in this part of the narrative and the representation, as focalized by Margot's consciousness, of the experience of speeding. I will also attempt to shed some light on the way in which gender and speed intersect in this part of The Revenge for Love. ${ }^{2}$ 
2 Briefly summarized, the aspects of the plot most relevant for understanding the section of narrative under study are as follows: Victor Stamp, an impecunious would-be artist, has been persuaded to participate in a gun-running operation managed by Sean O'Hara, a shady character who cynically uses communist activism as a money-making opportunity, in order to smuggle arms into Spain. ${ }^{3}$ Victor has accepted the mission not out of any real political conviction, but because he and Margot (who has lost her job after the closure of the local library she worked at) are in desperate financial straits. Like much else in the novel, however, Victor's mission is not what it seems: he is actually being used as a decoy to distract attention from the real operation, and the false-bottom of the car, as he subsequently discovers to his disgust, is full of bricks, not machine-guns. O'Hara has tipped off the Spanish authorities that Victor is running the operation and the house to which he is to deliver the weapons is surrounded by Civil Guards. Margot has already witnessed the capture of Percy Hardcaster, a committed communist activist who has been managing operations from the French border. As Victor heads unwittingly towards his capture, she flags him down and warns him that he is heading into a trap. The couple then take flight in the car from the trap that has been set for Victor in Figueras.

3 Just prior to the section under study we learn how Victor manages to set off on his mission in the first place, outwitting Margot's watchfulness-she has insisted on accompanying him to Spain in a protective bid to make sure he stays out of trouble-by pretending to want to paint. As soon as she is out of sight, Victor seizes his chance and departs; the car that plays a fateful role subsequently in the narrative is then described for the first time:

After a brief disturbance from within, there came a mighty purr from [the garage's] recesses, then an outsize and very handsome dove-grey roadster emerged. Its blunt imposing head appeared unexpectedly quickly for such an important accouchement, riding with drowsy power over the obstructions of the uneven soil. Victor was at the wheel. This monster, as it moved across the yard was gathering speed; it melted ponderously through the ungated entrance at the side of the hotel, bellowing like a poleaxed bullock. [...] Next moment it had slunk away, with velvet self-effacement, rolling upon a rich carpet of dust, sucked in at the gateway for some time after the great car had departed. (299)

The car, as Trevor Brent has observed, is depicted in terms "which invest it with a bestial power and will of its own" (Brent 479). ${ }^{5}$ Indeed, it is striking that the succession of intransitive verbs (emerge, appear, ride, move, melt, slink, roll, depart) depicting the car's motion deprive Victor of agency; significantly, he simply is "at the wheel", in that most basic of syntactical and existential relationships. ${ }^{6}$ The sheer length of the description granted the car, along with the extended participial phrases employed, also underlines the insignificance or reification of Victor: the latter's presence is merely tersely indicated in a succinct sentence enclosed in the lavish descriptive language devoted to the car; the human being has been subsumed, displaced, diminished by the machine. Furthermore, the narrator's withholding the use of the term "car" until the final clause and the mobilisation of synonyms (roadster, accouchement, monster) contribute to the impression of alienating awe inspired by the car which appears to be a creature rather than a machine. ${ }^{7}$ Its menacing potential is only heightened by the ostensible softness of the power it contains (mighty purr; drowsy power; melted ponderously; velvet self-effacement; rolling upon a rich carpet of dust); subsequently, 
when Margot and Victor take flight, the terrible violent potential of the car is unleashed.

When he is flagged down by Margot so close to his destination, Victor is somewhat displeased; we understand that he is ashamed and cross that he will not be able to carry out his manly mission owing to his wife's untimely interference. ${ }^{8}$ When they subsequently take flight together, Victor's frustration is mediated through the car, over which he now seems to exert a semblance of control. This signals the beginning of the extraordinary extended section of narrative where the experience of speeding in the car is related from Margot's point of view:

The car swept forward over the road, perversely ridged and gouged, and half the time they appeared to be shooting through the air, rather than running along a plane which should have been there but wasn't. On several occasions Margot flew up from her seat like a cork, and was almost lost out of the car. But to this Victor paid no attention whatever: if he had lost her out of the car, he would not have noticed it, she felt quite sure. Indeed, almost when this happened his foot was seen to crush down more cruelly on the accelerator; and Margot was obliged to cling to the safety straps and other available finger-holds, she was so volatile, to prevent a repetition of this contretemps.

Meanwhile, trees, rocks, and telegraph-poles stood up dizzily before her and crashed down behind. They were held up stiffly in front of her astonished eyes, then snatched savagely out of the picture. Like a card-world clacked cinematographically through its static permutations by the ill-bred fingers of a powerful conjurer, everything stood on end and then fell flat. He showed you a tree-a cardboard tree. Fix your eye upon this! he said. Then with a crash it vanished. Similarly with a segment of cliff. Similarly with a telegraph-pole.

Her head ached with the crash of images. Every time a telegraph-pole fell down she felt the shock of its collapse in the picture-house of the senses. This rushing cosmos filled her with a bleak dismay. She had not foreseen their mad charge through this forest of objects; and her senses quailed. (314)

\section{Lewis's critique of speed-worship}

Before examining in greater detail what Paul Edwards has justifiably described as the most impressive aspect of Lewis's writing in The Revenge for Love, namely the representation of Margot's experience of the car ride and Lewis's "stylistic capacity [...] to render the psychic shocks administered to consciousness as it is torn by the adjustments it must make in a world reshaped by speed and mechanical extension" (Edwards 2000, 450), it is worth recalling that Lewis had an intense dislike of speed, both as an aesthetic value and as a technological and sociological phenomenon. ${ }^{9}$ His qualms about speed were part of his broader scepticism regarding what he called "the power of the machine" (Lewis 1994, 96) and with what Lewis considered as the predominantly pernicious impact on human subjectivity of a world that was becoming more and more mechanized and increasingly in thrall to an ideology of progress represented by technological advances. ${ }^{10}$ In an essay titled "Power-Feeling and Machine-Age Art", published in 1934 while he was writing The Revenge for Love, Lewis pointed out that any technological advance tended to produce

people intoxicated with the novelty of a new toy, or with the unexpected power, amounting to veritable magic, conferred upon them thereby without any effort of their own, from one minute to the next. (Edwards 1989, 238) ${ }^{11}$ 
7 In the same essay Lewis also made the trenchant observation that technological advance was "in no way equated with an intellectual or spiritual advance" (Edwards 1989, 238). ${ }^{12}$ What Lewis called "machine-mindedness" (Edwards 1989, 236) amounted in essence to a dangerously uncritical submission to the blandishments of technology.

8 The episode set in the speeding car in The Revenge for Love can thus be seen to resonate with Lewis's life-long critique of the "Machine Age" (Lewis 1994, 96) and of technophilia in general, but it also represents an extension of his excoriation of the adulation of the motor car and the exaltation of what Lewis called "crude speed" (Edwards 1989, 238) ${ }^{13}$ by the Futurists, an enthusiasm evidenced by the number of Futurist paintings devoted to the representation of locomotion and speed. ${ }^{14}$ Indeed, in the 1910s Lewis had expended a great deal of time and energy asserting the superiority of the Vorticist aesthetic philosophy to that of Futurism, and one of his principal criticisms of the rival movement had been directed at what he saw as the Futurists' uncritical enthusiasm for the machine, manifested for instance in their romantic "worship of a Panhard racing-car" (Lewis 1986, 57). The Vorticist painters, as Paul Edwards has pointed out, "responded critically to the Futurists' celebration of the effects of machines and fast transport on our sense of ourselves" (Edwards 2000, 449). Deriding Futurism as "Automobilism" (Lewis 2002, 8), Lewis upbraided Marinetti for his "lyrical shouts about the God-Automobile" (Lewis 2000, 42) and his "rant about speed" (Lewis 1986, 74)..$^{15}$

9 The new ideal of mechanically-enabled speed was, of course, most notably canvassed by Marinetti in the founding Futurist Manifesto of 1909 and in "The New Religion-Morality of Speed" of 1916, from which the following act of speed-worship is taken:

Holiness of wheels and rails. We should kneel on the rails to pray to divine speed.

[...] The Inebriation of great speed in cars is simply the joy of feeling oneself merged with the only divinity. [...] The joy of shifting from third to fourth gear. Joy of pressing the accelerator pedal, roaring with musical velocity. (Rainey 225, 226; emphasis in original)

10 While Marinetti underlines the exhilaration and exultation-the "joy"-procured through speeding, the terms-"bleak dismay"-in which Lewis formulates Margot's reaction to her perception of the "rushing cosmos" from within the speeding car are the antithesis of the sensations that such an experience induced in a Futurist. ${ }^{16}$ Proclaiming their "scorn for women" (Apollonio 22), the Futurists famously celebrated the car as "the explicit symbol of the new speed culture" (Duffy 170), as the encapsulation of a new set of virile aesthetic values and as the vehicle, to use Lisa Tickner's words, of a "gleaming new Futurist masculinity" (Tickner 192) that surpassed and supplanted the traditional ideals of beauty as something static and feminine ${ }^{17}$ :

We affirm that the world's magnificence has been enriched by a new beauty: the beauty of speed. A racing car whose hood is adorned with great pipes, like serpents of explosive breath-a roaring car that seems to ride on grapeshot is more beautiful than the Victory of Samothrace. (Apollonio 21)

The breathless syntax deployed here seems expressive of the grandiose effusiveness that Lewis sardonically dismissed as "futuristic gush" (Lewis 2000, 41) in 1915. In the narrative constituting the founding myth of Futurism that precedes the manifesto, the Futurists' cars are compared to mythical "snorting beasts" which enable the Futurists to throw themselves "like pride-ripened fruit into the wide, contorted mouth of the wind" (Apollonio 20). As Hal Foster has underlined, the experience of speed for the Futurist subject is essentially one of renewal and of "ecstatic release" and helps bring 
into being a "renovated consciousness" (Foster 131) ${ }^{18}$ It is also a celebration of violence: during their inaugural joy-ride, Marinetti and his acolytes relish "hurling watchdogs against doorsteps, curling them under [their] burning tyres like collars under a flatiron" (Apollonio 20). (By way of contrast with the Futurists' thrill at flattening dogs, the narrator in The Revenge for Love notes Victor's avoidance of a canine collision: "A dog attempted suicide, but Victor prevented it, with an appropriate curse" (316).) Indeed, in the eyes of the Futurist the car's potential for inflicting violence (on its driver and passengers as well as bystanders) seems to be part of its aesthetic appeal, with the sound of grapeshot and explosions only further enhancing its beauty.

The inaugural Futurist joy-ride famously culminates in a muddy ditch by the side of the road into which Marinetti is forced to steer the car to avoid two hapless cyclists approaching-symbolically of course-from the opposite direction. Having undergone this symbolic death, the Futurist is triumphantly reborn thanks to what turns out to have been a muddy baptism through technology; a new "technological subject" (Foster 118) emerges from the primitive slime: "When I came up-torn, filthy and stinkingfrom under the capsized car, I felt the white-hot iron of joy deliciously pass through my heart!" (Apollonio 21). Even the car, flipped upside-down "like a big beached shark" (Apollonio 21), is rehabilitated at a touch: "They thought it was dead, my beautiful shark, but a caress from me was enough to revive it; and there it was, alive again, running on its powerful fins!" (Apollonio 21).

Lewis's take on the impact of speed on the human subject experiencing it is radically different: the symbolic death and rebirth in the Futurist manifesto are replaced by very real stakes in The Revenge for Love, where there is no rebirth, no coming back to life. In the course of their flight from capture, Margot and Victor inadvertently become murderers when, on failing to stop at a checkpoint, their car hits and kills a Civil Guard. Subsequently, the "roadster" is defeated by there being no more road, and the dismembered car from which Margot and Victor try to extract some of the supposedly hidden arms is described from her point of view as "this big murderous dove-grey body, all opened up, like the carcass of a captured shark" (331). The predatory nature of the eviscerated car is emphasized as it finally yields up its fake cargo and reveals the extent of the illusions under which Victor has been operating. It seems more than a mere coincidence that the speeding narratives in both The Revenge for Love and the Futurist manifesto also contain two identical animal referents-namely the shark and the dog-the differing treatment of which subtly emphasizes the disparity between the two texts in their depictions of the experience and the effects of speeding. Having abandoned the obsolete and duplicitous car, Margot and Victor then set off on a shepherd's track into the Pyrenees in the midst of a storm only to meet their deaths by falling off a precipice (this outcome is mediated through a newspaper report handed to the imprisoned Percy Hardcaster in the final chapter).

The year in which The Revenge for Love was published, 1937, also saw the publication of Lewis's first autobiography, Blasting and Bombardiering. Describing the controversy between Vorticism and Futurism which had reached its height in 1914, Lewis recalled a conversation he claimed to have had with Marinetti in which the flamboyant Italian expressed his surprise at Lewis's lack of enthusiasm for the sensation of speeding: "You have never known the ivresse of travelling at a kilometre a minute. Have you ever travelled at a kilometre a minute?" Lewis's response was that of a visual artist for whom "the clearness of outline, the static beauty, of the things you commonly 
apprehend" was essential (Lewis 1993, 167): "I loathe anything that goes too quickly. If it goes too quickly it is not there. [...] I cannot see a thing that is going too quickly" (Lewis 1982, 34-35). As Paul Edwards explains, Lewis was hostile to speed because it "dissolves the material world" (Edwards 2000, 104). If Lewis's loathing of speed is echoed, as I have already suggested, in Margot's perception and experience of speeding in The Revenge for Love, the fact that her perception is represented principally in visual terms is also a reflection of Lewis's status as an artist and his belief in the visual-in "the wisdom of the eye" (Lewis 1987, 105)-as the primary (and primal) human sense. Hence the metaphor "the picture-house of the senses" (314) in the passage from The Revenge for Love quoted above.

\section{Seeing while at speed}

For Margot, however, it seems to be less a case of speed making one unable to see objects clearly or at all than being forced to adopt a radically altered, and even violent, way of seeing. Indeed, seeing while speeding is painful and a source of intense suffering for Margot: "Her head ached with the crash of images" (314). It is, moreover, an experience that is inflicted upon her, as the powerless passenger in the car driven by her husband, rather than willingly embraced. Margot's painful seeing-at-speed corresponds to what Enda Duffy, in The Speed Handbook, describes as a "limit-gaze", which he defines as the "effortful, stressful and wilful act at the margin of the humanly possible" (Duffy 162) that the speeding subject has to perform in order to see. Although Duffy argues that the blur, "the effective erasure of the visible", became the "dominant trope for representing what was seen at speed from the car" (Duffy 175), Margot does not see a blur but the rapid, jerky and violent appearance and disappearance of roadside objects in something akin to a grotesque version of the childhood game of 'now-you-see-it, now-you-don't'. ${ }^{19}$ The violent, radically destabilizing oscillations between presence and absence are conveyed by the antithetical verbal pairs that structure the second paragraph of the passage quoted earlier: stood up/crashed down; held up/snatched (out of the picture); stood upon end/fell flat; showed/vanished. These oppositions set up a powerful binary tension suggestive of the violent extremes of the experience that Margot is undergoing. The figure of the ethically suspect "powerful conjurer" not only constitutes a sinister personification of the phenomenon of speed but also alludes to one of the central themes of the novel: the pervasiveness of different types of illusion and manipulation. ${ }^{20}$ As at other times in the novel, Margot feels she is being deceived at the hands of cunningly malevolent forces, but here the lexis of illusion (picture, card-world, conjurer, cardboard, picture-house) also foregrounds the radical unreality of the world as she perceives it from the speeding car and suggests the alienating nature of the experience. As Enda Duffy has pointed out, cars "delivered defamiliarising shocks, stunning their users with the shock of the new" (Duffy 5). For Margot, speed reveals the world in a way she has never experienced before, transforming it into a grotesque version of itself where everything is 'out of joint'. By clinging on to safety straps and finger-holds she attempts to counteract this experience of extreme visual and physical destabilisation and dislocation ${ }^{21}$. Violence is also inflicted by the rapid appearance and disappearance of fragments of the outside world, other things which Margot is invited to cling on to visually-to "fix her eye on"-by the duplicitous conjurer. The violent excess or extravagance of the experience is inscribed even in the lopsided structure of the principal sentence in the second 
paragraph where the polysyllabic terms in the extended adverbial phrase give way abruptly to the short main clause which consists predominantly of monosyllabic words: "everything stood upon end and then fell flat". The visual hypotyposis here is overlaid with traces of the other senses: "crash" and "clack" denote not just a physical action visually perceived (with the repetition of "crash" perhaps registering Margot's subliminal fear as to one possible outcome of the car-ride), but also suggest the noises that accompany Margot's experience of speeding; the repetition of hard / $/ \mathrm{k} /$ and $/ \mathrm{g} /$ sounds throughout the second paragraph can be seen as mimicking the aggressive "clacking" of the conjurer's cards and the rattling of the car as it hurtles over the uneven road. The psychological and visual pummelling Margot is undergoing in the speeding car-the "violation of [her] psyche", as Paul Edwards has eloquently put it (Edwards 2000, 50)-is akin to the process that Hal Foster has described, using appropriately Vorticist terms, as "the blasting of the subject" (Foster 131).

Later on, Margot realises that a collision with the Civil Guard is inevitable; careering towards him, she closes her eyes against the impact only for her way of seeing to be altered once more:

when [her eyes] came open again they had a glaze of sorts, that veiled them to induce in them a partial vision, like that of smoked glass. Screaming after the manner of an express plunging into a tunnel, she went into it, except that this darkness was picked out in vivid patches of violent fact. For all that, it was no longer the light of day, but a highly selective order of blackout. A crude salience was given to items of importance; to the rest it applied its inky sponge. Surrounding the things that were thus picked out, stood a nocturnal haze. What she saw appeared to her in fragments, but in too great detail, for it was incoherent. (321, emphasis in original)

The "static permutations" between presence and absence in the earlier passage have now transmuted into radical and painful contrasts between darkness and light, haziness and vividness. Piecemeal and impaired vision seems to be symptomatic of a psyche under extreme pressure; in other words, the "limit-gaze" has reached its limit and is in the process of breaking down: "things would not stop apart" (322). The world this excruciated gaze encompasses consists of a "welter" (322) of shattered fragments. Indeed, after Margot and Victor have collided with and killed the Civil Guard, Margot herself seems to have undergone a form of fragmentation; she finds herself split in two, her body hurtling along in the car while in her mind's eye she hovers over the Civil Guard's body as she struggles to visualise it:

she discovered herself at last watching against her will the floodlit stretch of rustred road. Plumes of dust were spurting up; but their car (it had left her behind) was rapidly disappearing and had already grown quite small, in diminishing perspective; while in the foreground she was staring down at a disagreeable flattened object. Sprawling in the centre of the road, it was incredibly twodimensional and, in short, unreal. It might just have been painted on the earth. But it looked more like a big untidy pattern, cut out of black paper, except for what was the face. That was flat, as well-as flat as a pancake, but as pale as a sheet, with a blue smear where the chin was. It was the chin of Prussian-blue. The flat black headgear of a Civil Guard, likewise no thicker than cardboard, lay a foot away from the head. (325)

Even the split self is split here: Margot sees herself watching against her will. Lexis from the fields of visual and plastic art (diminishing perspective, foreground, twodimensional, painted, pattern, paper, sheet, cardboard), which is also suggestive of the context of the illuminated theatre stage, contributes to another striking hypotyposis, 
evoking a traumatised way of seeing. What Lewis represents is Margot's shocked attempt to visualise the aftermath of the collision she has just been involved in; the sheer unreality of this visualisation, with its cartoonish insistence on the twodimensionality of the dehumanised victim of the car is an index of the trauma she has undergone..$^{22}$ The pancake-flatness of the murdered Civil Guard is also reminiscent of the dogs that the Futurists had relished curling "like collars under a flat-iron" in the course of their inaugural joy-ride; once more though, what such similes imply differs radically between the Futurist Manifesto and The Revenge for Love.

\title{
Gendered perceptions of speed
}

19 From the beginning of the traumatic car-journey, Margot had sought to put up some sort of psychological resistance to the alienating effects of speed, as can be seen from the extract below (which follows on from the end of the first long passage quoted earlier):

\begin{abstract}
Above all, she detested this charging beast, that muscular machine. Pounding beneath her, it carried her forward, she knew, by means of unceasing explosions. Very well. But in this act she must cooperate. To devour miles and to eat up minutes, in gulp after gulp, use must be made of her organs, so it seemed, as well as its own. Under her feet she had a time-eating and space-guzzling automaton, rather than a hackneyed means of transport, however horridly high-powered. It was her time, too, it was gobbling up-under great pressure, in big passionate draughts. [...] She disliked its psychological habits even more than its physiological habits, which was saying quite a lot, the latter being disagreeable enough in all conscience. (314)
\end{abstract}

Margot's repugnance at being overpowered, subsumed and even consumed by the car recalls-at the same time as it contrasts with-Marinetti's thrill at being flung by the automobile "into the wide, contorted mouth of the wind" (Apollonio 20). Plunged into a vortex of violence in the speeding car, Margot struggles to retain her demeanour and resist its physical and psychological assaults. ${ }^{23} \mathrm{Her}$ mind's eye therefore envisions for her a more palatable, seemly and civilised alternative to the grotesque reality to which the roaring car in which she is still imprisoned is subjecting her:

An airplane, she had been told, had none of this crude speeding passion which these things on wheels developed. You could take your hands off it, lounge back to savour the polar scenery of floodlit cloudbanks, beneath the lunar arclight-perspectives much to her fancy-through which it would continue smoothly to rush, a gentlemanly Pegasus. (315)

Margot's musings on the comfort of air travel reflect the fact that, as Enda Duffy has observed, the sensation of speeding in a plane is fundamentally different to that experienced in a car owing to the plane's remoteness from stationary surroundings (Duffy 17). Indeed, the repetition of soft /l/ and /s/ phonemes here perhaps help evoke the serene sensation of speeding in a plane. The final image of this romantic musing, this alternative dreamscape to the nightmare being experienced-the aeroplane as a "gentlemanly Pegasus"-points up the gender dynamics at work in Lewis's representation of the experience of speed. Indeed, Margot's revulsion at-and disapproval of-the vulgar violence of the speeding car is implicitly represented as a stereotypically feminine reaction to masculine crudeness; the "gentlemanly Pegasus" of the aeroplane seems to be a form of transport more suited to Margot's feminine 
sensibility than the distinctly un-gentlemanly automobile which she also thinks of as "a disagreeable fellow" (315):

...this tearing of the air was positively uncouth. How men could put up with that wind as they did she could not quite imagine. Women in windjammers would be quite out of the question! One's ears were converted into whistles, which was a stupid prank, when upon both sides of one's head! Also for two pins it would whistle in one's teeth! (315, emphasis in original)

Thus, in addition to the psychological and physical violence it inflicts, the experience of speeding in a car also seems to represent an offence against Margot's feminine sensibility. The indignation expressed through the free indirect speech here is formulated from a stereotypically feminine perspective, with Margot's gendered outlook underlined by the verbal inflections the narrator employs to render her thoughts.

When Victor stops to pick up Margot on his approach to Figueras, for example, there is something like an abrupt collision between the feminine and the masculine domains: Margot enacts what the narrator-in a passage focalised through Victor's consciousness -calls her "timid hold-up" (310):

The car rushed up to the place where the pale hand still languidly tossed in the dust-storm in the wake of its wheels [...]. Out of the brown cloud came the diminutive figure, all in due course, up to the side of the footboard, stumbling a little, and coughing quietly, repressing the big reactions to mouthfuls of hot dust. (309)

The vocabulary employed here (pale, diminutive, languidly, a little, quietly) all points to Margot's stereotypically feminine fragility, something which is further underlined when Victor contemplates "his immaterial wife": "this papier-mâché figure-a whitish flutter of cotton, a palish, expressionless wedge of a face, a pair of nervous hands" (309). ${ }^{24}$ The repetition of the adjectival suffix -ish is significant here, I think, because Lewis frequently deploys it to suggest the indeterminacy and vagueness characteristic of what he defines as the romantic and the feminine: "something very dishevelled, ethereal and misty" (Lewis 1987, 153). While Margot's femininity is foregrounded, Victor is represented as stereotypically masculine in his breezy, ingenuous boisterousness and his physical vigour and vitality. His strikingly robust looks contrast sharply with the description of Margot just cited:

The big, lean Australian head, as if chopped out of brown indiarubber [sic], showed up well in the Spanish sun. The long, muscular pits of its dimples equably displayed their ascetic lines. (310)

Moreover, Victor's well-defined physical appearance reflects his mental outlook; he sees "a world of black and white, composed of clear-cut individuals" (310). In other words, there is nothing -ish about Victor. A man of few words and something of a Candide figure, Victor is incapable of taking appearances other than at face value or of conceiving that his bosses could manipulate or betray him. He is incredulous of Margot's suspicions that he is being manipulated. Forced by his wife to envisage the possibility that he has been set up, his only frames of reference are those of the adventure narratives of popular culture; he cannot begin to believe he has been cast as "the captain of the Forty Thieves!" (317) or as "Public Enemy No. 1" (317); he can only put the forging of his signature (which led to his identification as the ringleader of the gun-runners) down to "a pretty harmless practical joke" (317). Margot, in turn, 
rationalises Victor's betrayal of her for his adventure in the car by means of the clichéd thoughts: "Men will be men" (315) and "Oh, these handsome men!" (316).

Victor's lack of insight, which Margot recognises as "the traditionally imperfect vision of these starry six-footers" (331), means that he has, according to Lewis, traits in common with Frederic Henry, the hero of Hemingway's Farewell to Arms. Lewis had underlined Henry's "really heroic imperviousness to thought" (Lewis 1987, 22) in one of a series of critical essays on literature and in defence of satire that were published in 1934 under the Hemingway-inspired title Men without Art, while Lewis was writing The Revenge for Love (Hemingway had published Men without Women, a collection of short stories, in 1927). In a letter defending the critical stance adopted in his essay on Hemingway, Lewis refers rather disparagingly to the latter's "he-man purposes" (Rose 1963, 223), using an epithet that links Hemingway to Victor, who is himself described as a "he-man" (311) in the course of the car-episode. In this episode Victor is represented through references to male gender stereotypes and predominantly from the outside, through his speech and actions: he is described as a "Constant Cowboy" (311), a "manof-action" (313) ${ }^{25}$, "Man with a capital letter" (318) and a "Kipling Man" (318) with a "Clark Gable" smile (330). Victor is clearly upset ("ashamed") that Margot's intervention will prevent him from carrying out his heroic gun-smuggling mission, turning-this in italics in the text as if to foreground its clichéd status-"strong and silent" (314), and punishing her initially through accelerating the car. Later on, Victor is so closely associated with his "speed-toy" (330) that he is even described as "the man that was a car" (321). Victor thus seems to operate in what Peter Schwenger has called the "masculine mode", which is characterised by a mistrust of words and reflects "one of the most powerful archetypes of manhood", namely "the idea that the real man is the one who acts rather than the one who contemplates" (Schwenger 110). Victor, as Paul Edwards has pointed out, "exemplifies the virtues of 'Kipling Man' as an easily duped man of action" (Edwards 2000, 449), but he also turns out to be, just like some of Hemingway's characters as Lewis sees them, one of "those to whom things are done" (Lewis 1987, 36). When Margot's suspicions that Victor has been set up are reinforced even further after the car's cargo of bricks is revealed, Victor, his outraged masculinity making itself fully apparent, can only exclaim: "My rôle was to be the decoy-duck!" (330). Realising he has been cynically manipulated, Victor's self-image is dented, his masculine bravado undermined, as his appalled reference to himself as a "decoy-duck" suggests (bird imagery is associated throughout the novel with the female protagonist). Both Margot and Victor seem to have internalised and thus to live up to gender stereotypes.

In Men without Art Lewis foregrounded and criticised what he called "classification by gender", taking to task what he considered to be the "feminine standpoint" (Lewis 1987, $131,132)$ and the stereotypically-gendered aesthetics of one of his principal literary enemies, Virginia Woolf. Lewis felt it necessary to point out

how illusory this division [between the Masculine and the Feminine departments of the universe] is found to be, upon inspection: to point out that many women are far more grenadiers or cave-men than they are little balls of fluff; and that, on the other hand, many men are much more fluffy and 'girlish' than are their sisters: that a veneer of habit, and a little bit of hair on the chin and chest, is about all that fundamentally separates one sex from the other. (Lewis 1987, 131-32) Margot can certainly be seen as "fluffy" and "girlish" ${ }^{26}$, and Victor as a "grenadier"- 
was deliberate and not merely an (unconscious) reflection of contemporary models of femininity and masculinity. As the quotation from Men without Art implies, Lewis believed that gender was a sociocultural construction ${ }^{27}$, and in The Revenge for Love Lewis suggests that Margot's idea of herself as a woman and her understanding of her relationship with Victor have been substantially shaped by her reading. Margot is represented as an avid reader of Virginia Woolf, whose writings, Lewis implies, have imparted to her a romantic and sentimental view of the world, leading her to acquire "unreal values" (Lewis 1987, 182) as Lewis put it in Men without Art ${ }^{28}$. Elsewhere in The Revenge for Love, the tenor of Margot's reading material leads to her being described as a "self-consecrated Bloomsbury priestess" (215) and as dwelling in a "highbrow' feminist fairyland" (214). Indeed, Woolf's A Room of One's Own (1929), Ruskin's “Of Queens' Gardens" from Sesame and Lilies (1865), and Tennyson's Maud (1855) all furnish prominent inter-textual references in Lewis's novel; they have all, the narrator informs us, helped "suckl[e] her starved intelligence and fed it with Victorian lollypops" (319). ${ }^{29}$ In other words, these can be thought of as texts that convey, as Lewis put it in Men without Art, spurious ideals about being "womanly-women or mothers of men" (Lewis 1987, 142). Both the title of the section of narrative under study, "Honey-Angel", and Margot's function within it are a horribly ironic reflection of Ruskin's conception of woman as "a gentle angel, bringing courage and safety by her presence" (Ruskin para. 57), because Margot's adherence to Ruskin's strictures for women and her intervention in order to save Victor actually lead to their deaths. ${ }^{30}$ After the collision with the Civil Guard, Margot reflects bitterly on her responsibility in his murder and her desire to live up to Ruskinian feminine ideals:

She had made everything a hundred times worse by what she had done. And she had been well-meaning! More than that, she had aimed at something of more positive virtue, like the fortitude of women in the grand rôles of this life. (326)

Fredric Jameson has pointed out that Margot's understanding of the world is distorted by "cultural forces" which leave her defenceless (Jameson 85). ${ }^{31}$ Significantly, one of the cultural forces or ideologies in which The Revenge for Love's protagonists find themselves trapped are stereotypical gender roles: Victor's status as an actionoriented, yet ultimately frustrated, Kipling Man and Margot's feminine romantic idealism contribute, with tragic consequences, to both protagonists lacking the lucidity (and the cynicism) to understand before it is too late the mechanics of the cruel plot in which they find themselves inextricably embroiled.

\section{Conclusion}

Focusing on the blasting of Margot's feminine subjectivity will draw together some of the points made so far. Margot's way of seeing, her visual perception of the world, are violently disrupted and altered in the course of the car journey. However, her way of seeing is also transformed on a far more figurative level: in the car she is brutally confronted with a violent reality which does not fit with her somewhat sentimental view of the world, with what is described elsewhere in the novel as a "saccharine type of seeing" (83)..$^{32}$ Her experience of speeding is apocalyptic (in the etymological sense of an uncovering, a revelation), and the narrative, as we have seen, shows her struggling to hold at bay and then to process the violence of the experience she is undergoing. ${ }^{33} \mathrm{At}$ the same time, however, Lewis also satirises Margot's feminine sense of decorum and propriety as she vainly attempts to retain her ladylikeness under the most traumatic of 
circumstances. After Margot and Victor have hit and killed the Spanish Guard, for instance, Margot's femininity does not admit the violent reality she is experiencing; she is unable to accept that the "sharp raps" on the car are bullets-they are first thought to be the noise of "a paper bag of wind, that had banged very near her" (322). Her thoughts then domesticate the violence in progress when she perceives the noise of the bullets as "reports from men's dress-shirts" (322). When Victor declares that it is fortunate that the car is armour plated, Margot's thoughts are utterly incommensurate with the situation:

He was praising the horrid old car now-that Victor was a boy who was fond of cars she had always known. But about this one he seemed perfectly potty-that was why Victor had run away, just to be able to drive it! Silly boy! He had trompéd her with a machine! (323)

31 These clichéd terms are those of a jealous young woman denouncing the amount of attention her beau lavishes on his motorcar; in other words the safety straps that Margot clung to in the car earlier in the narrative seem to have evolved into the psychological safety straps of familiar discourse and situations. ${ }^{34}$

If Margot attempts to domesticate the trauma she is undergoing it nevertheless remains discernible in the shape of the grin and grimace which seem to operate asultimately inadequate-defence mechanisms: she grins when she initially sees the two Civil Guards blocking the road (320); shortly after, we are told, "her teeth came out grinning against the shock, like a cat's at bay" (321). After Victor and Margot have hit and killed the Civil Guard, we learn that "her mouth [was] distended in a wide protective grimace" (322). ${ }^{35}$ Subsequently she is depicted as "smiling most frightfully, like a limerick 'young lady' of the nonsensical Lear" (324), and described as "smiling roguishly to herself and attempting to look like a lady" (324). Margot's grin seems to be the symptom of an increasingly desperate attempt to retain a semblance of femininity and self-control and to repress the scream of terror that eventually forces itself out. ${ }^{36}$ Just before the collision, we learn that "she released a long chuckling scream, clawing at her mouth to hold in this offensive outburst" (321). Margot's violent and instinctive physiological reaction and her vain attempt to retain her decorum are here violently juxtaposed, underlining once more the extreme pressure she is undergoing. In other words she is being torn apart by trauma while what Lewis elsewhere calls the "primitive brain" overwhelms the conscious mind and reveals the irrepressible reflexes of the "wild body" (Lewis 2002, 133). ${ }^{37}$ The final image the narrator paints of Margot before we learn of her death is that of her laughing uncontrollably after the nature of the car's real cargo-bricks-has been revealed:

she laughed outright at the absurdity of it. She laughed loudly and without restraint. A false bottom-a false bottom on wheels; but all full of nothing at all, except packing-paper and bricks! The joke grew on her, the more she thought about it. She went on laughing more and more. (331)

Laughter, as Lewis wrote elsewhere, "occasionally takes on the dangerous form of absolute revelation" (Lafourcade 1982, 158)..$^{38}$ The false-bottomed car takes Margot on a journey to her own heart of darkness as well as, more broadly, to a discovery of some of the darkest workings of human society. Margot's unrestrained, paroxysmal laughter at the uncovering of the bricks reflects the violence of the apocalyptic experience she has undergone and testifies to the "intense and even painful sense of the absurd" (Lewis 1987, 232) which has been revealed to her, shattering all her illusions about the "grand role" she has attributed to herself along with her Ruskinian and Woolfian feminine 
ideals. ${ }^{39}$ Her unchecked laughter at this point contrasts markedly with the "quiet" coughing with which she repressed the "big mouthfuls of hot dust" thrown up by the speeding car earlier on and suggests the extent to which Margot's ladylike subjectivity has been blasted and undone in the course of what Victor describes as "no joy-ride" (328).

What could thus be described as the anti-joy-ride at the climax of The Revenge for Love is an extraordinary piece of writing in which Lewis brilliantly renders the various stages of the traumatic experience Margot undergoes in the car driven by her husband. At some twenty years' distance this episode revisits and critically rewrites the Futurist adulation of speed, but it also resonates with Futurism's infamous "scorn for women" since Lewis chose to narrate the experience of speeding from the point of view of the female protagonist, the entrapped passenger in the speeding car. Gender-stereotypical ways of seeing, as I have tried to show, figure prominently in the portrayal of Margot (and Victor), yet the satirical elements in Lewis's representation of his female protagonist coexist with a great deal of pathos. Margot's plight, as Jeffrey Meyers has argued, is "portrayed with extraordinary insight and compassion" (Meyers 227), and Bernard Lafourcade is right to describe The Revenge for Love as both "extremely droll and perfectly painful" (Lafourcade 1980, 14; my translation). ${ }^{40}$ The experience of speeding in a car certainly gives Margot, like the Futurists, a new perspective on reality, a new sense of herself and a different "type of seeing" (83), but for her they prove wholly destructive.

\section{BIBLIOGRAPHY}

Apollonio, Umbro (ed.). Futurist Manifestos. Boston: MFA Publications, 2001.

Brent, Trevor. "Keeping Up Appearances: Reality and Belief in Wyndham Lewis's Time and Western Man and The Revenge for Love." Textual Practice 22:3 (2008): 469-86.

Duffy, Enda. The Speed Handbook. Velocity, Pleasure, Modernism. Durham and London: Duke University Press, 2009.

Edwards, Paul (ed.). Creatures of Habit and Creatures of Change. Essays on Art, Literature and Society, 1914-1956. By Wyndham Lewis. Santa Rosa: Black Sparrow, 1989.

---. “Signifying Nothing: The Revenge for Love." Enemy News 15 (1982): 13-22.

---. Wyndham Lewis, Painter and Writer. New Haven: Yale University Press, 2000.

Foster, Hal. Prosthetic Gods. Cambridge: MIT Press, 2004.

GĄsiorek, Andrzej. Wyndham Lewis and Modernism. Tavistock: Northcote House, 2004.

Jameson, Fredric. Fables of Aggression: Wyndham Lewis, the Modernist as Fascist. Berkeley and London: University of California Press, 1979.

Lafourcade, Bernard. "Introduction". La Rançon de l'amour. By Wyndham Lewis. Translated by Bernard Lafourcade. Lausanne: l'Age d'homme, 1980. 7-16. 
---. (ed.). The Complete Wild Body. By Wyndham Lewis. Santa Barbara: Black Sparrow Press, 1982. Lewis, Wyndham (ed.). BLAST. A Review of the Great English Vortex. 1914. Ed. Bradford Morrow. Santa Rosa: Black Sparrow, 2002.

---. (ed.). BLAST. A Review of the Great English Vortex. War Number. 1915. Santa Rosa: Black Sparrow, 2000.

---. Blasting and Bombardiering. An Autobiography (1914-1926). 1937. London: Calder, 1982.

---. Men without Art. 1934. Ed. Seamus Cooney. Santa Rosa: Black Sparrow, 1987.

---. The Art of Being Ruled. 1926. Ed. Reed Way Dasenbrock. Santa Rosa: Black Sparrow, 1989.

---. The Caliph's Design. Architects! Where is your Vortex? 1919. Ed. Paul Edwards. Santa Barbara: Black Sparrow, 1986.

---. (ed.). The Enemy No. 2: A Review of Art and Literature. 1927. Ed. David Peters Corbett. Santa Barbara: Black Sparrow, 1994.

---. The Revenge for Love. 1937. Ed. Reed Way Dasenbrock. Santa Rosa: Black Sparrow, 2000.

---. Rude Assignment. An Intellectual Autobiography. 1950. Santa Rosa: Black Sparrow, 1984.

---. Time and Western Man. 1927. Ed. Paul Edwards. Santa Rosa: Black Sparrow, 1993.

Mayoux, Jean-Jacques. “L'Amour puni”. BLAST 3. Ed. Seamus Cooney et al. Santa Barbara: Black Sparrow, 1984. 144-49.

Meyers, Jeffrey. The Enemy: A Biography of Wyndham Lewis. London: Routledge \& Keegan Paul, 1980.

Rainey, Lawrence et al. Futurism: An Anthology. New Haven and London: Yale University Press, 2009.

Rose, W. K. The Letters of Wyndham Lewis. By Wyndham Lewis. London: Methuen, 1963.

Ruskin, John. Sesame and Lilies. 1865. http://www.bartleby.com/28/7.html Accessed 31 August 2014.

Schwenger, Peter. “The Masculine Mode." Speaking of Gender. Ed. Elaine Showalter. Routledge: New York and London, 1989. 101-12.

Scragg, Andrew. "Wyndham Lewis and Ernest Hemingway: Beyond the 'Unsuccessful Rapist' and the 'Dumb Ox"'. The Journal of Wyndham Lewis Studies 4 (2013): 81-103.

Simmel, Georg. "The Metropolis and Mental Life." 1903. Modernism: An Anthology of Sources and Documents. Ed. Vassiliki Kolocotroni et al. Edinburgh: Edinburgh University Press, 1998. 51-60.

Tickner, Lisa. Modern Life and Modern Subjects. British Art in the Early Twentieth Century. New Haven: Yale University Press, 2000.

\section{NOTES}

1. Another form of popular culture may also have had some bearing on Lewis's conception of this part of the plot: the car chase in film. The speeding car, as Enda Duffy has pointed out in The Speed Handbook, has been a cinematographic favourite since the very earliest films (Duffy 7, 153). 2. In so far as speed does not feature throughout the narrative, the speeding episode in Lewis's novel corresponds to the tendency Enda Duffy has identified as follows: "most of the literature of speed consists of flashes in the panoramas of larger fictions" (Duffy 271). 
3. Lewis was at this point extremely hostile to communism, describing it in a letter of 1934 as "a religion: and a particularly bloodthirsty and persecutory one at that" (Rose 226).

4. In order to facilitate their identification as such, citations from The Revenge for Love will be referenced between simple parentheses in the text.

5. A few pages later, when Victor is approaching Figueras, the car is once more depicted as a muscular feline predator: "The large dove-grey car was leaping at it, in powerful elastic bounds, of transatlantic nervosity" (309). The ternary structure of this sentence-the commas that divide it into three parts are not strictly necessary syntactically or semantically-perhaps helps suggest the aggressive roars of the "bounding" car.

6. Brent puts this as follows: "Although Victor is at the wheel and ostensibly in control of the car, he seems to be little more than an accessory: the car moves itself, Victor merely sits inside it" (Brent 479).

7. Paul Edwards perceptively observes that "the car does not negate, but rather intensifies nature, resuming within itself the purr of the cat, the colour of the dove, the bellow of the slaughtered bullock" (Edwards 2000, 449).

8. Victor is also surprised at how quickly Margot has caught up with him, for speediness certainly does not seem to be one of his wife's principal characteristics. Victor muses on her "uncanny velocity" (310) as follows, his frustrated artistic ambitions shaping the form his thoughts take: "Victor recognized with amusement that this was a singular feat, her turning up as she had. His Margot had beat [sic] the band, in the matter of efficient locomotion! She must have chartered an aeroplane! For how had she done it, if not by air? Or she must have arrived like the Egyptian symbol of the psyche. That was more like her than Imperial Airways! Whizzing over the mountains (his memory supplied the picture of a winged objet d'art in paint or gypsum), she had dropped down to ambush him just as he was about to reach his destination" (310).

9. Lewis gave the accelerated pace of modern life as one of his motivations for writing his massive tome, Time and Western Man (1927): "Hurrying, without any significant reason, from spot to spot at the maximum speed obtainable, drugged in that mechanical activity, how is the typical individual of this epoch to do some detached thinking for himself?" (Lewis 1993, xi).

10. It is important to recall that Lewis nevertheless welcomed the revolutionary aesthetic possibilities offered by the ubiquity of machinery in modern life, pointing out that it was inevitable-and even desirable-that artists should include in their work "something of the lineaments and character of machinery" (Lewis 1986, 57). He observed, however, that it was necessary to have "a deliberate and reasoned enthusiasm for the possibilities that lie in this new spectacle of machinery; of the use to which it can be put in art" (Lewis 1986, 57).

11. This infantilising description of technophiles is reflected in The Revenge for Love where the car is dubbed "that big speed-toy" (330).

12. Lewis also gives a moral dimension to his scepticism about the machine when he describes "the evil inherent in that merely physical power" as being "piled up in contradiction to the spirit" (Lewis 1994, 96).

13. Echoing this terminology, the narrator of The Revenge for Love evokes the "crude speeding passion" (315) of the car.

14. For instance, the following are the titles of some of Giacomo Balla's early works: Speeding Automobile (1912), Abstract Speed (1913), Rhythm + Noise + Speed of Car (1913), The Speed of an Automobile (1913), Velocity of Cars and Light (1913).

15. Lewis also sardonically remarked that the English did not need "a prophetic Milanese to tell them that Motor-Cars go quickly, or are amusing, because they have already noticed that for themselves" (Edwards 1989, 33). The ultimate put-down, however, was perhaps: "AUTOMOBILISM bores us" (Lewis 2001, 8). In a letter written as late as 1941 Lewis once more deplored Marinetti's "epileptic outpourings in praise of speed and force" (Rose 310; emphasis in original). 
16. The echoes between Marinetti's manifesto and this episode in Lewis's novel have been briefly touched on by Paul Edwards (2000) and Trevor Brent in their studies of The Revenge for Love. Later in the novel we are told that entering the gorge in the Pyrenees also "filled [Margot] with dismay" (328). The lexis and the syntactical structure used in the passage quoted above form a proleptic link with the experience Margot has in the car to the fate-death-which awaits Victor and her in the mountains.

17. Speed, Enda Duffy reminds us, "has almost wholly been presented as a male desire" (Duffy 53).

18. Hal Foster has also described this process in Freudian terms as one of "unbinding" (Foster 118).

19. Duffy also refers to "the shock effect of multiple images that appear to rush up close and then zip by on either side" (Duffy 164).

20. Elsewhere in the novel the narrator evokes "the manipulative deftness of the conjurer, poker-faced and lightning-fingered" (154).

21. It is Fredric Jameson who describes Margot's experience as "the painful dislocation of consciousness" (Jameson 83).

22. Bernard Lafourcade points out that a grotesque reality has become a collage (Lafourcade 1982, 412), while Trevor Brent astutely observes that the "artificiality and unreality [of the description of the Civil Guard] reduce the form of the human person to a collection of nonhuman things, arranged in the manner of a modernist collage" (Brent 480).

23. Margot's objections to what is happening to her also exemplify what Georg Simmel famously described, in his study of the perils of modernity, as "the resistance of the individual to being levelled, swallowed up, in the social-technological mechanism" (Simmel 52).

24. In fact, the narrator refers twice to Margot's "diminutive figure" within the space of two paragraphs. Margot's physical, feminine fragility is emphasized in the passage leading up to the flight by car: Margot's waving Victor down is described as "a feeble signal", "like a person waving last farewells in dream"; she greets him by "clamour[ing] mildly" (309) and is referred to as "this wraith of a small wondering woman" (311).

25. Lewis later observed that the "veneration for action, and for men of action is a feature of Twentieth Century thinking", adding that Hemingway was "an obvious instance of a writer whose muse is married to Action" (Lewis 1984, 35).

26. Victor himself employs the term "girlish" earlier in The Revenge for Love to express his dissatisfaction with the style of his paintings which he judges "dulcet and vapid, like the sweettooth of the immature and the girlish" (83). Lewis derided what he called the "girlish" (Lewis 1987, 143) nature of Byron, Wilde and Huysmans in Men without Art (1934) and wrote in "Detachment and the Fictionist", another essay from 1934, that it was "girlish" to prevaricate and to refuse to take sides in an argument (Edwards 1989, 228).

27. His awareness of the discursive and cultural construction of gender, however, did not prevent Lewis, with his characteristically binary thought patterns, from almost consistently categorising what he disapproved of as pertaining to the "eternal feminine" or "the essentially feminine sensibility" (Lewis 1987, 133, 145; emphasis mine).

28. Lewis actually uses the expression "unreal values" in connection with Walter Pater, one of Woolf's intellectual mentors, but it is clear that Lewis also considers Woolf to be a purveyor of similarly obsolete values. Citing Woolf's "Mr Bennett and Mrs Brown" (1923) in Men without Art, Lewis accuses Woolf of producing "a quite false picture of the true aspect of our scene" and of maliciously misrepresenting contemporary literature as inclined to be "pale and dishevelled" (Lewis 1987, 138, 134).

29. Margot, as Andrzej GĄsiorek has observed, is a "product of ideological interpellation", and "her Bloomsbury feminism, her Romantic view of a beneficent nature, and her faith in love are exposed as the constituent features of her 'sham culture outfit"' (GĄsiorek 96). 
30. It is Margot who suggests to Victor that they abandon the car somewhere and return to France on foot through the Pyrenees (313). In "Of Queens' Gardens" Ruskin glosses Shakespeare as follows: "The catastrophe of every play is caused always by the fault or folly of a man; the redemption, if there be any, is by the wisdom and virtue of a woman, and failing that, there is none" (Ruskin, para. 57).

31. Jameson remarks that The Revenge for Love constitutes "a thoroughgoing critique of Margot's immaturity, and of the cultural forces which have left her thus defenceless" (Jameson 85). Likewise, Paul Edwards has intimated that Margot's "Anglo-Saxon sham culture outfit has confined her within a humanitarianism that is inappropriate to the actual conditions of life" (Edwards 2000, 452). Lewis argued in Men without Art that English liberalism was based "upon false sentiment" (Lewis 1987, 191) and denounced, as part of his justification of satire, what he thought of as contemporary British society's inability to face up to brutal realities, notably when these took the form of social revolution (as is the case in The Revenge for Love, of course), whereby "budding Olivias, instructed to be little Victorians, living under the sheltering shadow of the Prince Consort, are scarcely likely to be prepared, when the time comes, for all the things that are in store for them. For many of them must be blown to pieces" (Lewis 1987, 203). In The Revenge for Love Lewis portrays Margot as one such "budding Olivia".

32. Men without Art was in great part a complex defence of satire as representing an "objective, non-emotional truth"; Lewis denounced "spurious, sugared" representations of reality" (Lewis $1987,99,203)$ and derided what he considered to be Woolf's feeble and fearful Bloomsbury way of seeing whereby "The mind's eye [...] perceives the actual scene a little dimly, at the best peeps out on the contemporary scene" (Lewis 1987, 120). After the collision with the Civil Guard, of course, Margot sees the actual scene "a little dimly" and finds herself "peeping out". In Lewis's view, satire was bound to appear "'grotesque' or 'distorted' to those accustomed to regard the things of everyday, and everyday persons, through spectacles couleur-de-rose" (Lewis 1987, 99-100). The Revenge for Love shows that the shock and trauma (perhaps themselves also effects induced in the viewer/reader by satire?) undergone by Margot in the speeding car also give rise to such grotesque and distorted appearances.

33. Trevor Brent's study offers an interesting interpretation of Margot's experience as coming into contact with the Lacanian 'real'.

34. In a similar vein, Margot's final thoughts before she begins to be able to piece together what has occurred are: "What a ride this had been!" (323). Once more, the inappropriateness of the formulation to the situation suggests her struggle to make the horrific familiar and thus somehow psychologically manage the trauma that she has undergone.

35. Margot's "protective grimace" contrasts with the glee with which the Futurists flung themselves into the "wide contorted mouth of the wind".

36. The text is pervaded by references to Margot's contorted facial expressions: "grinning fiercely" (324); "grinning in her corner" (325); "her grimacing mouth" (327); "grinned stupidly" (331).

37. When she realises that Victor does not intend to stop at the checkpoint, Margot pleads with him to obey the guards and is once more depicted as subject to contradictory impulses: "in a shrill bay the genteel organ of everyday broke forth-her neck thrust out in rooster-fashion" (320; emphasis mine). Note the male bird imagery employed in this depiction of the breakdown of Margot's "genteel" femininity.

38. Laughter, according to Lewis, was also the "characteristic expression" of a "wild nihilism" (Lewis 1987, 232).

39. The title Lewis had originally wanted to give his novel, "False Bottoms", also suggests that what happens to Margot is the destruction of her illusions, of her own false bottom. In Men without Art, Lewis wrote that "true satire" had a "painful effect" (Lewis 1987, 90). 
40. For Meyers, The Revenge for Love is Lewis's "first humanistic novel" (Meyers 223). For Paul Edwards, too, this novel marks a new departure for Lewis and "coincides with [his] abandonment of his clamorous insistence on 'the outside of things', the demise of the 'Enemy', and a humanising of his outlook" (Edwards 1982, 15).

\section{ABSTRACTS}

This study focuses on the narrative section which forms the climax of Wyndham Lewis's 1937 novel The Revenge for Love and which represents the experience of speeding in a car from the point of view of the female protagonist, Margot Stamp. I argue that Lewis's depiction of speed in his novel extends his critique of the technophilia he dubbed "machine-mindedness" and alludes to, at the same time as it implicitly criticises, the Futurist adulation of speed. As a visual artist, Lewis represents the experience of speeding as a violently distorted and traumatic way of seeing and also satirises female gender stereotypes in his representation of Margot's experience of speeding.

Cette étude traite de la représentation de l'expérience de la vitesse dans The Revenge for Love (La Rançon de l'amour), un roman de Wyndham Lewis publié en 1937. L'épisode en question est raconté du point de vue de Margot Stamp, la protagoniste du roman, laquelle se trouve piégée dans une voiture conduite à toute vitesse par son mari. La représentation de la vitesse traduit le scepticisme de Lewis vis-à-vis de la technophilie, mais elle renferme également des allusions implicitement critiques à l'adulation futuriste de la vitesse. En tant qu'artiste visuel, Lewis représente l'expérience de la vitesse comme une façon de voir qui est violemment déformée et traumatisante. Il satirise également des stéréotypes féminins dans sa représentation de l'expérience vécue par Margot.

\section{INDEX}

Mots-clés: genre, Futurisme, satire, vitesse, Vorticisme

Keywords: gender, Futurism, satire, speed, Vorticism

\section{AUTHORS}

\section{ANNELIE FITZGERALD}

Maître de conférences

Université Toulouse - Jean Jaurès

annelie.fitzgerald@univ-tlse2.fr 